\title{
ДЕТЕРМІНАНТИ ЗЛОВЖИВАННЯ АЛКОГОЛЕМ НАСЕЛЕННЯМ ЗАКАРПАТТЯ
}

\author{
ДУ «Український інститут стратегічних досліджень Міністерства охорони здоров'я України», \\ м. Київ, Україна
}

\begin{abstract}
Мета: дослідити детермінанти зловживання алкоголем населенням Закарпаття.
Матеріали і методи. У роботі використано статистичний (дані галузевої статистичної звітності за 2010-2014рр.) та соціологічний (опитано 400 жителів Закарпатської області) методи.

Результати. Найважливішими соціальними детермінантами, які виступають фракторами ризику розвитку алкоголізму у дорослого населення Закарпатської області (прямий сильний кореляційний зв'язок), є безробіття, самотність, несприятливий психологічний клімат у сім'ї (конфрліктна сім'я), відсутність постійного місця проживання, а медичними, відповідно, ВІЛ-інорікування. До економічних детермінант розвитку алкоголізму із прямим сильним кореляційним зв'язком належать недостатність фрінансів на найважливіші потреби родини (бідність), непостійний заробіток та наявність при собі надлишкових грошей.

Висновки. Визначення детермінант розвитку алкоголізму серед дорослого населення Закарпатської області $€$ основою для розробки комплексної регіональної програми профрілактики алкоголізму.
\end{abstract}

КЛЮчОВІ СЛОВА: алкоголізм; соціальні, медичні, економічні детермінанти.

У сучасних умовах суспільного розвитку з притаманними йому глобалізацією, швидкою урбанізацією, комерціалізацією, маркетизацією, значною неконтрольованою мобільністю, агресивною рекламою алкоголю, збільшенням доступності алкогольних напоїв, населення багатьох країн світу стикається зі зростанням тягаря хвороб, пов'язаних із нездоровою поведінкою, перш за все через шкідливе вживанню алкоголю $[1 ; 3]$.

Алкоголь виступає провідним фактором ризику, займаючи провідні місця за впливом на формування глобального тягаря хвороб у багатьох країнах [8]. За даними ВООЗ, шкідливе вживання алкоголю $є$ причинним фрактором понад 200 порушень здоров'я, пов'язаних із хворобами і травмами. Близько 5,1\% загального глобального тягаря хвороб і травм обумовлено алкоголем за оцінками в показниках DALY. Дослідження «Глобальний тягар хвороб, травм і причин ризику» (2010р.) показало, що протягом 19902010 рр. втрата здорових років життя в результаті вживання алкоголю збільшилася на 32\%. Споживання алкоголю призводить до смерті та інвалідності на більш ранніх стадіях життя людини [2]. Серед населення у віці 20-39 років приблизно 25\% усіх випадків смерті пов'язані з алкоголем. Алкоголь - одна з провідних причин передчасної смертності чоловіків у віці 40-60 років, що обумовлює розрив у тривалості життя чоловіків і жінок. Існує причинно-наслідковий зв'язок між шкідливим вживанням алкоголю і цілим рядом психічних і поведінкових розладів, інших не-

\footnotetext{
(C) В.В. Кручаниця, 2016
}

інфрекційних порушень здоров'я, а також травм [4]. Встановлено причинно-наслідкові зв'язки між шкідливим вживанням алкоголю і захворюваністю на туберкульоз, а також ВІЛ/СНІД. Крім наслідків для здоров'я шкідливе вживання алкоголю завдає значних соціальних та економічних збитків окремим людям і суспільству в цілому. Завдана алкоголем шкода виходить за рамки фрізичного і психологічного здоров'я осіб, що ним зловживають [5;7]. Він серйозно позначається на добробуті суспільства, здоров"ї та якості життя оточуючих [6].

Мета роботи: дослідити детермінанти зловживання алкоголем населенням Закарпаття.

Матеріали та методи. У ході роботи використані статистичний (дані галузевої статистичної звітності за 2010-2014рр.) та соціологічний (опитано 400 жителів Закарпатської області) методи. Роздано 500 анкет, отримано заповненими 437, статистично опрацьовано 400. При анкетуванні збережено конфіденційність даних про респондентів.

Результати дослідження та їх обговорення. Аналізуючи середньорічні показники захворюваності дорослого населення на алкоголізм у розрізі адміністративних районів області, можна констатувати, що найвищий показник рівня захворюваності зареєстровано у Мукачівському (228,83 на 100 тис. дорослого населення), Берегівському (179,372 відповідно), Міжгірському (164,532 відповідно) районах. Найнижчий рівень показників захворюваності дорослого населення на алкоголізм зареєстровано у Хустківському (43,938 відповід- 
но), Свалявському (62,578 відповідно), Великоберезнянському (62,684 відповідно) районах. Різниця показників рівнів захворюваності на алкоголізм у розрізі адміністративних територій області становить 5,2 разу ( $\mathrm{p} \leq 0,01)$. У табл. 1 наведено середньорічні рівні показників захворюваності дорослого населення Закарпатської області на алкоголізм у розрізі адміністративних територій.

Таблиця 1. Рейтингові рівні середньорічних показників захворюваності дорослого населення Закарпатської області на алкоголізм у 2012-2015 рр., на 100 тис. відповідного населення

\begin{tabular}{|c|c|c|c|}
\hline \multirow{2}{*}{ Адміністративна територія } & \multicolumn{2}{|c|}{ Рейтингові рангові позиції } & \multirow{2}{*}{$\begin{array}{c}\text { Середньорічний показник } \\
\text { захворюваності на алкоголізм }\end{array}$} \\
\hline & рейтинг & ранг & \\
\hline Берегівський район & 1 & \multirow[t]{2}{*}{1} & 244,92 \\
\hline Міжгірський район & 2 & & 212,65 \\
\hline Мукачівський район & 3 & \multirow[t]{2}{*}{2} & 197,27 \\
\hline Перечинський район & 4 & & 162,03 \\
\hline Тячівський район & 5 & \multirow[t]{7}{*}{3} & 148,90 \\
\hline Рахівський район & 6 & & 140,66 \\
\hline Ужгородський район & 7 & & 135,62 \\
\hline Виноградівський район & 8 & & 119,27 \\
\hline м. Ужгород & 9 & & 116,91 \\
\hline Великоберезнянський район & 10 & & 113,31 \\
\hline Свалявський район & 11 & & 101,72 \\
\hline Іршавський район & 12 & \multirow[t]{2}{*}{4} & 95,97 \\
\hline Воловецький район & 13 & & 89,92 \\
\hline Хустський район & 14 & 5 & 48,48 \\
\hline
\end{tabular}

Подібна територіальна характеристика встановлена і щодо середньорічних рівнів показників поширеності алкоголізму серед дорослого населення Закарпатської області в розрізі адміністративних територій (табл. 2). Найвищі показники поширеності алкоголізму зареєстровано у Міжгірському (2953,4 на 100 тис. дорослого населення), Перечинському (2067,02 відповідно), Рахівському (20,55 відповідно) районах. Найнижчі рівні захворюваності дорослого населення на алкоголізм зареєстровано у Іршавському (1437,3 на 100 тис. дорослого населення), Воловецькому (1462,3 відповідно), Хустському (1506,7 відповідно) районах. Різниця показників рівня захворюваності на алкоголізм у розрізі адміністративних територій області становить 2,05 разу ( $\mathrm{p} \leq 0,05)$.

Аналіз отриманих результатів показує, що різниця в адміністративно-територіальному аспекті середньорічних показників рівнів поширеності серед дорослого населення алкоголізму становить $2,1$ разу ( $\mathrm{p} \leq 0,05)$ - від 1444,77 у Хустському до 3049,64 у Міжгірському районі.

Далі вивчалися соціальні детермінанти, які впливають на рівень захворюваності дорослого населення Закарпатської області на алкоголізм. У табл.3 наведено рангову структуру, кореляцію їі величини та сили соціальних детермінант розвитку алкоголізму у дорослого населення області.

Соціальні детермінанти різною мірою можуть виступати фракторами ризику розвитку алкоголіз- му. Як видно із даних табл. 3, прямий сильний кореляційний зв'язок встановлено між показником наявності алкоголізму у дорослого населення Закарпатської області і такими соціальними детермінантами, як безробіття, самотність, несприятливий психологічний клімат у сім'ї (конфрліктна сім'я), повна сім'я з проблемними дітьми. Прямий кореляційний зв'язок середньої сили встановлено між показником наявності алкоголізму у дорослого населення і такими соціальними детермінантами, як несприятливі умови проживання (до 5 кв. м житлової площі на члена сім'ї без зручностей), трудова міграція та робота на керівних посадах, а прямий кореляційний зв'язок слабкої сили - 3 наявністю у сім'ї осіб, які потребують постійного догляду, за відсутності відповідних житлових і побутових умов та робота приватним підприємцем.

Дані про рейтингову структуру і кореляцію деяких медичних детермінант розвитку алкоголізму у дорослого населення наведено в табл. 4. Як видно 3 таблиці, важливими медичними детермінантами у дорослого населення Закарпатської області (прямий сильний кореляційний зв'язок із наявністю алкоголізму) виступає ВІЛ-інфікування. Менше значення, як фрактор ризику розвитку алкоголізму, має захворювання на туберкульоз (прямий кореляційний зв'язок середньої сили) і незначним фрактором ризику (прямий слабкий кореляційний зв'язок) $€$ наявність у дорослого населення працездатного віку інвалідності та злоякісних новоутворень. 
Таблиця 2. Рейтингові рівні середньорічних показників поширеності алкоголізму серед дорослого населення Закарпатської області, на 100 тис. відповідного населення

\begin{tabular}{|c|c|c|c|}
\hline \multirow{2}{*}{ Адміністративна територія } & \multicolumn{2}{|c|}{ Рейтингові рангові позиції } & \multirow{2}{*}{$\begin{array}{l}\text { Середньорічний показник } \\
\text { поширеності алкоголізму }\end{array}$} \\
\hline & рейтинг & ранг & \\
\hline Міжгірський район & 1 & \multirow[t]{2}{*}{1} & 3049,64 \\
\hline Великоберезнянський район & 2 & & 2657,05 \\
\hline Перечинський район & 3 & \multirow[t]{2}{*}{2} & 2114,53 \\
\hline Рахівський район & 4 & & 2048,57 \\
\hline Свалявський район & 5 & \multirow[t]{8}{*}{3} & 1985,50 \\
\hline Тячівський район & 6 & & 1925,53 \\
\hline Берегівський район & 7 & & 1872,54 \\
\hline Мукачівський район & 8 & & 1858,19 \\
\hline м. Ужгород & 9 & & 1686,40 \\
\hline Ужгородський район & 10 & & 1543,17 \\
\hline Виноградівський район & 11 & & 1533,28 \\
\hline Іршавський район & 12 & & 1514,65 \\
\hline Воловецький район & 13 & \multirow[t]{2}{*}{4} & 1494,50 \\
\hline Хустський район & 14 & & 1444,77 \\
\hline
\end{tabular}

Таблиця 3. Рейтингова структура і кореляція деяких соціальних детермінант розвитку алкоголізму у дорослого населення Закарпатської області

\begin{tabular}{|c|c|c|c|}
\hline Соціальні детермінанти & Рейтинг & $\begin{array}{r}\text { Коесріцієнт } \\
\text { кореляції }\end{array}$ & $\begin{array}{c}\text { Спрямованість зв'язку } \\
\text { та його сила }\end{array}$ \\
\hline Безробіття & 1 & $+0,74$ & Прямий сильний зв'язок \\
\hline Самотність & 2 & & \\
\hline $\begin{array}{l}\text { Несприятливий психологічний клімат } \\
\text { у сім'ї. Конорліктна сім'я }\end{array}$ & 3 & $+0,64$ & Прямий сильний зв'язок \\
\hline Відсутність постійного місця проживання & 4 & $+0,62$ & Прямий сильний зв'язок \\
\hline Трудова міграція & 5 & $+0,53$ & Прямий зв'язок середньої сили \\
\hline $\begin{array}{l}\text { Несприятливі умови проживання: } \\
\text { до } 5 \text { кв. м на члена сім'ї без зручностей }\end{array}$ & 6 & $+0,48$ & Прямий зв'язок середньої сили \\
\hline Робота на керівних посадах & 7 & $+0,43$ & Прямий зв'язок середньої сили \\
\hline Повна сім'я з проблемними дітьми & 8 & $+0,32$ & Прямий зв'язок середньої сили \\
\hline $\begin{array}{l}\text { Наявність у сім'ї осіб, які потребують } \\
\text { постійного догляду, за відсутності } \\
\text { відповідних житлових та побутових умов }\end{array}$ & 9 & $+0,28$ & Прямий слабкий зв'язок \\
\hline Робота приватним підприємцем & 10 & $+0,19$ & Прямий слабкий зв'язок \\
\hline
\end{tabular}

Таблиця 4. Рейтингова структура і кореляція деяких медичних детермінант розвитку алкоголізму у дорослого населення Закарпатської області

\begin{tabular}{|l|c|c|l|}
\hline \multicolumn{1}{|c|}{ Медичні детермінанти } & Рейтинг & $\begin{array}{c}\text { Коефіцієнт } \\
\text { кореляції }\end{array}$ & \multicolumn{1}{|c|}{ Спрямованість зв'язку та його сила } \\
\hline ВІЛ-інорікований & 1 & $+0,68$ & Прямий сильний зв'язок \\
\hline Хворий на туберкульоз & 2 & $+0,35$ & Прямий середньої сили зв'язок \\
\hline Хворий на злоякісне новоутворення & 3 & $+0,20$ & Прямий слабкий зв'язок \\
\hline Інвалід у осіб працездатного віку & 4 & $+0,16$ & Прямий слабкий зв'язок \\
\hline
\end{tabular}

Встановлено прямий сильний зв'язок розвитку алкоголізму 3 такими економічними детермінантами, як недостатність фрінансів на найважливіші потреби родини, непостійний заробіток та постійна наявність при собі надлишкових грошей, а також встановлено прямий зв'язок середньої сили з наявністю великих нетрудових доходів. 
Таблиця 5. Рейтингова структура і кореляція деяких економічних детермінант розвитку алкоголізму у дорослого населення Закарпатської області

\begin{tabular}{|l|c|c|l|}
\hline \multicolumn{1}{|c|}{ Економічні детермінанти } & Рейтинг & $\begin{array}{c}\text { Коефіцієнт } \\
\text { кореляції }\end{array}$ & Спрямованість зв'язку та його сила \\
\hline $\begin{array}{l}\text { Недостатність фрінансів на найважливіші } \\
\text { потреби родини }\end{array}$ & 1 & $+0,75$ & Прямий сильний зв'язок \\
\hline Непостійний заробіток & 2 & $+0,63$ & Прямий сильний зв'язок \\
\hline Постійно має при собі надлишкові гроші & 3 & $+0,61$ & Прямий сильний зв'язок \\
\hline Великі нетрудові доходи & 4 & $+0,51$ & Прямий зв'язок середньої сили \\
\hline
\end{tabular}

\section{Висновки}

У ході проведеного дослідження встановлено, що середньорічний рівень захворюваності дорослого населення на алкоголізм у розрізі адміністративних районів Закарпатської області відрізняється у 5,1 разу (від 48,48 до 244,92 на 100 тис. дорослого населення), а поширеності - у 2,1 разу (від 1444,77 до 3049,64 відповідно).

Найважливішими соціальними детермінантами, які виступають фракторами ризику розвитку алкоголізму у дорослого населення Закарпатської області (прямий сильний кореляційний зв'язок), $€$ безробіття, самотність, несприятливий психологічний клімат у сім'ї (конфрліктна сім'я), відсутність постійного місця проживання; а медичними, відповідно, - ВІЛ-інфрікування. До економічних детермінант розвитку алкоголізму із прямим сильним кореляційним зв'язком виступають недостатність фрінансів на найважливіші потреби родини (бідність), непостійний заробіток та наявність при собі надлишкових грошей.

Перспективи подальших досліджень пов'язані з розробкою принципів первинної профрілактики алкоголізму у населення Закарпаття.

\section{Список літератури}

1. Доклад о ситуации в области неинфекционных заболеваний в мире, 2010 г. -Женева : ВОЗ, 2013. - 170 с.

2. Кручаниця В. В. Смертність населення Закарпатської області внаслідок вживання алкоголю / В. В. Кручаниця // Україна. Здоров'я нації. - 2015. - № 2 (34). - С. 59-62.

3. Медико-соціальні аспекти вживання алкоголю населенням та стратегії протидії / Грузєва Т. С., Дусринець В. А., Замкевич В. Б. [та ін.] // щорічна доповідь про стан здоров'я населення, санітарно-епідемічну ситуацію та результати діяльності системи охорони здоров'я України. 2015 рік / за ред. В. В. Шафранського. - Київ, 2016. - С. $118-127$.

4. Ринда Ф. П. Алкоголізація населення України як один з головних чинників поширення ХНІЗ / Ф. П. Ринда // Матеріали III Міжнар. мед. конгр. [«Впровадження сучасних досягнень медичної науки в практику охорони здоров'я України»], (Київ, 14-16 жовт. 2014 р.): тези доп. - С. 8.

5. Ринда Ф. П. Алкогольна проблема та шляхи вирішення в Україні / Ф. П. Ринда // Матеріали міжнародної науковопрактичної конференції ["Актуальні питання фрормування здорового способу життя та використання оздоровчих технологій"], (Херсон, 25-27 черв. 2014 р.): тези доп. - С. 77-80.

6. Ринда Ф. П. Стан і проблеми наркоманії та алкоголізації населення / Ф. П. Ринда, В. В. Кручаниця // щорічна доповідь про стан здоров'я населення, санітарно-епідемічну ситуацію та результати діяльності системи охорони здоров'я України. 2014 р. / за ред. Квіташвілі О. ; МОЗ України, ДУ «УІСД МОЗ України». - Київ : МВЦ «Медінформ», 2015. - С. $128-138$.

7. Рівень поширеності і тенденції вживання тютюну, алкогольних напоїв, наркотичних речовин серед учнівської молоді України : аналіт. звіт / Укр. ін-т соц. досліджень ім. О. Яременка. - Київ, 2011. - 178 с.

8. Слабкий Г. О. Щодо тягаря проблем в Україні, пов'язаних зі споживанням алкоголю / Г. О. Слабкий, В. В. Кручаниця, А. Г. Круть // Україна. Здоров'я нації. - 2016. - № 1-2 : Матеріали Міжнародної науково-практичної конфреренції «Можливості превентивного та лікувального впливу на соціально значимі захворювання в закладах первинної медико-санітарної допомоги» (12-13 квітня 2016 року, м. Ужгород). - С. 258-259.

\section{References}

1. Doklad o situatsyi v oblasti neinfektsyonnykh zabolevaniy v mire, $2010 \mathrm{~h}$. [Report on the World Situation with NonInfectious Diseases, 2010]. (2013). Geneva: WHO [in Russian].

2. Kruchanytsya, V.V. (2015). Smertnist naselennya Zakarpatskoi oblasti vnaslidok vzhyvannya alkoholyu [Mortality in Transcarpathian region due to alcohol consumption]. Ukraina. Zdorovya natsii - Ukraine. Health of the Nation, 2 (34), 5962 [in Ukrainian].

3. Hruzyeva, T.S., Dufynets, V.A., Zamkevych, V.B., Rynda F.F., \& Kruchanytsya V.V. (2016). Medyko-sotsialni aspekty vzhyvannya alkoholyu naselennyam ta stratehii protydii [Medical and social aspects of the population alcohol consumption and prevention strategy]. Shchorichna dopovid pro stan zdorovya naselennya, sanitarno-epidemichnu sytuatsiyu ta rezultaty diyalnosti systemy okhorony zdorovya Ukrainy. 2015 rik - Annual Report on the State of Health, Sanitary and Epidemic Situation and the Performance of the Health Care System in Ukraine. V.V. Shafranskyi (Ed.). Kyiv [in Ukrainian]. 
4. Rynda, F.P. (2014). Alkoholizatsiya naselennya Ukrainy yak odyn z holovnykh chynnykiv poshyrennya KhNIZ [Alcoholism of population in Ukraine as one of the main factors of the CNID spread]. Proceedings of the Congress: III Mizhnarodnyi medychnyi konhres «Vprovadzhennya suchasnykh dosyahnen medychnoi nauky v praktyku okhorony zdorovya Ukrainy» - The 3rd International Medical Congress «The introduction of modern achievements of medical science in public health practice in Ukraine» (p. 8). n.d. N.p. [in Ukrainian].

5. Rynda, F.P. (2014). Alkoholna problema ta shlyakhy vyrishennya v Ukraini [Alcohol problem and its solution in Ukraine]. Proceedings of the Scientific and Practical Conference: «Aktualni pytannya formuvannya zdorovoho sposobu zhyttya ta vykorystannya ozdorovchykh tekhnolohiy» - International Scientific Conference «Actual issues of healthy lifestyle and use of health technologies» (pp. 77-80). n.d. N.p. [in Ukrainian].

6. Rynda, F.P., \& Kruchanytsya, V.V. (2015). Stan i problemy narkomanii ta alkoholizatsii naselennya [State and problems of drug and alcohol abuse of population]. Shchorichna dopovid pro stan zdorovya naselennya, sanitarno-epidemichnu sytuatsiyu ta rezultaty diyalnosti systemy okhorony zdorovya Ukraiiny 2014 - Annual report on the state of health, sanitary and epidemic situation and the performance of the health care system in Ukraine 2014. O. Kvitashvili (Ed.). (pp. 128-138.). Kyiv: IEC «Medinform» [in Ukrainian].

7. Level of spreading and trends in tobacco, alcohol, drug use among youth in Ukraine: analytical report (2011). Kyiv. n.d. [in Ukrainian].

8. Slabkyi, H.O., Kruchanytsya V.V., \& KrutA.H. (2016). Shchodo tyaharya problem v Ukraini, povyazankh zi spozhyvannyam alkoholyu [The burden of problems in Ukraine related to the consumption of alcohol]. Ukraiina. Zdorovya natsii. - Ukraine. Health of the Nation, 1-2, 258-259 [in Ukrainian].

\section{ДЕТЕРМІНАНТЫ ЗЛОУПОТРЕБЛЕНИЯ АЛКОГОЛЕМ НАСЕЛЕНИЕМ ЗАКАРПАТЬЯ}

\section{В.В. Кручаница}

ДУ «Украинский институт стратегических исследований Министерства здравоохранения Украини», г. Киев, Украина

Цель: исследовать детерминанты злоупотребления алкоголем населением Закарпатья.

Материалы и методы. В работе использованы статистический (данные отраслевой статистической отчетности за 2010-2014 гг.) и социологический (опрошено 400 жителей Закарпатской области) методы.

Результаты. Наиболее важными социальными детерминантами, которые выступают фракторами риска развития алкоголизма у взрослого населения Закарпатской области (прямая сильная корреляционная связь), являются безработица, одиночество, неблагоприятный психологический климат в семье (конорликтная семья), отсутствие постоянного места жительства, а медицинским, соответственно, ВИЧ-инфицирование. К экономическим детерминантам развития алкоголизма с прямой сильной корреляционной связью принадлежат нехватка фринансов на нужды семьи (бедность), непостоянный заработок и наличие при себе лишних денег.

Выводы. Определение детерминант развития алкоголизма среди взрослого населения Закарпатской области является основой для разработки комплексной региональной программы профилактики алкоголизма.

КЛЮЧЕВЫЕ СЛОВА: алкоголизм, детерминанты социальные, медицинские, экономические.

\section{DETERMINANTS OF ABUSING ALCOHOL BY THE POPULATION OF TRANSCARPATHIAN REGION V.V. Kruchanytsia \\ PE «Ukrainian Institute of Strategic Research MHC of Ukraine», Kyiv, Ukraine}

Goal of research: to study the determinants of alcohol abusing by the population of Transcarpathian region.

Materials and methods used in the course of study: statistical (data of branch statistical reporting for the years 2010-2014), sociological (400 residents of Transcarpathian region interviewed).

Results. Unemployment, loneliness, poor psychological climate in the family (conflict family), the absence of permanent residence are the most important social determinants and HIV-infection is the most important medical determinant that work as risk factors for development of alcoholism among adult population of Transcarpathian region (direct strong correlation link). Lack of finance for the most important needs of the family (poverty), inconstant earnings and permanent availability of the surplus money belong to economic determinants of the development of alcoholism with direct strong correlation link.

Conclusion. Detection of the determinants of alcoholism development among the adult population of Transcarpathian region composes the base for working out the integrated regional program for prevention of alcoholism.

KEY WORDS: alcoholism; social, medical, economic determinants.

Рукопис надійшов до редакції 16.12.2016 р.

Відомості про автора:

Кручаниця Василь Васильович - пошукувач ДУ «Український інститут стратегічних досліджень Міністерства охорони здоров'я України»; тел. служб.: +38(044) 576-41-19. 